\title{
Analiza stabilności i szerokiej adaptacji plonu ogólnego bulw odmian ziemniaka uprawianych na glebie lekkiej
}

\author{
Analysis of stability and wide adaptation of total tuber yield of potato varieties \\ grown on light soil
}

Joanna Jankowska®, Milena Pietraszko

\author{
Instytut Hodowli i Aklimatyzacji Roślin - Państwowy Instytut Badawczy, Oddział w Jadwisinie, \\ ul. Szaniawskiego 15, Jadwisin 05-140, \\ $\bowtie$ e-mail: j.jankowska@ihar.edu.pl
}

\begin{abstract}
The aim of the study was to assess the agricultural stability and the degree of wide adaptation of the total tuber yield of potato varieties grown in the years 2014-2017. For the analysis, 34 potato cultivars of different maturity groups of different uses were selected. The application was made using the AMMI model. Measures were used to evaluate the wide adaptation: superiority measure $P_{i}$, Eskridge'y yield reliability measure $R_{i}$ and a measure of Kang stability $Y S_{i}$. For the analyzed parameters, significant differences between years, varieties and genotype $\times$ year interaction were shown. Agriculturally stable varieties were obtained: seven in the total tuber yield. The ranking of varieties made it possible to conclude that the highest degree of wide adaptation in terms of the total yield was shown by the varieties: Mondeo, Ignacy, Gwiazda, Denar, Michalina and Lord.
\end{abstract}

\begin{abstract}
Key words: genotype $\times$ year interaction, potato, stability, total tuber yield
Celem badań była ocena stabilności rolniczej i stopnia szerokiej adaptacji plonu ogólnego bulw odmian ziemniaka uprawianych w latach 2014-2017 w centralnej Polsce (IHAR-PIB Oddział w Jadwisinie). Do analizy wytypowano 34 odmiany ziemniaka różnych grup wczesności o różnym przeznaczeniu. Wnioskowanie wykonano stosując model AMMI. Do oceny szerokiej adaptacji wykorzystano miary: nadrzędności plonowania $P_{i}$, miarę niezawodności przewagi plonowania $R_{i}$ (tzw. miarę Eskridge'a) oraz miarę stabilności Kanga $Y S_{i}$. Dla analizowanych parametrów wykazano istotne różnice pomiędzy latami, odmianami oraz interakcję genotyp $\times$ rok. Wyłoniono siedem odmian ziemniaka plonujących stabilnie. Ranking odmian pozwolił na stwierdzenie, że największy stopień szerokiej adaptacji pod względem plonu ogólnego wykazały odmiany: Mondeo, Ignacy, Gwiazda, Denar, Michalina i Lord.
\end{abstract}

\section{Słowa kluczowe: interakcja genotyp x rok, ziemniak, stabilność, plon ogólny bulw}

Producenci ziemniaka potrzebują odmian o wysokim potencjale plonotwórczym, odpornych na choroby oraz plonu o wysokiej jakości bulw. Plon jest jedną z najbardziej złożonych cech ziemniaka i zależy od uwarunkowanego genetycznie potencjału plonotwórczego odmiany oraz od jej reakcji na warunki środowiskowe. Dlatego też w analizie wyników doświadczeń odmianowych najbardziej interesująca, z punktu widzenia oceny stabilności i zdolności adaptacyjnej, jest interakcja genotypowo-środowiskowa (GxE). Zróżnicowane reakcje roślin na czynniki środowiskowe, takie jak temperatura, wilgotność, gleba, obserwowane w różnych miejscach i latach wynikają $\mathrm{z}$ interakcji zachodzącej pomiędzy genotypem i środowiskiem. Wyniki tej interakcji stanowią bardzo ważną informację o odmianie zarówno dla hodowców ziemniaka jak i rolników. Dają wiedzę o zachowaniu się odmian oraz ich reakcji na polepszenie lub pogorszenie warunków uprawy [Caliński 1967; Mądry i in. 2010]. Za najbardziej pożądane w hodowli, a później w uprawie, uważa się odmiany stabilne, o szerokiej zdolności adaptacyjnej, plonujące stosunkowo wysoko niezależnie od warunków. Wyniki oceny stabilności plonowania pozwoliłyby na wiarygodną rekomendację odmian do uprawy. Wskazanie odmian ziemniaka najlepiej plonujących w zróżnicowanych warunkach pogodowych czy siedliskowych, mogłoby stanowić uzupełnienie badań porejestrowych prowadzonych przez COBORU (Centralny Ośrodek Badań Odmian Roślin Uprawnych), na podstawie których aktualnie tworzona jest Lista odmian zalecanych do uprawy na obszarze województwa.

W literaturze dotyczącej stabilności odmian można spotkać dwie normy stabilności: stabilność w sensie biologicznym oraz stabilność 
w sensie rolniczym [Becker, Leon 1988; Galek i in. 2000]. Genotyp względem danej cechy jest stabilny w sensie biologicznym, jeżeli średnia wartość cechy nie zmienia się w różnych środowiskach. Stabilność w sensie rolniczym oznacza, że średnia wartość cechy zmienia się proporcjonalnie do przeciętnej reakcji w różnych środowiskach. Przeciętna reakcja jest określana za pomocą średnich środowiskowych dla danej cechy [Becker, Leon 1988; Galek i in. 2000; Mądry, Rajfura 2003].

Metody statystyczne pozwalające ocenić stabilność odmian opierają się na modelach, stanowiących różne rozwinięcia modelu stałego i mieszanego jednozmiennej analizy wariancji dla dwukierunkowej klasyfikacji krzyżowej z interakcją [Bombik $i$ in. 2003]. W ostatnich latach rozwinięto wykorzystanie modelu AMMI oraz biplotów typu GGE [Yan i in. 2007; Padarewski, Mądry 2012]. Coraz częściej w opracowaniach dotyczacych badania interakcji odmian ze środowiskiem spotyka się ocenę ich stopnia szerokiej adaptacji. Według Iwańskiej i in. [2008], szeroką adaptacją odmiany określamy zdolność odmiany do relatywnie wysokiej produktywności, wyrażonej zdolnością do tworzenia plonu na relatywnie wysokim poziomie $w$ zmiennych warunkach środowiskowych rejonu, lat lub systemów uprawy. Opracowano wiele metod i towarzyszących im miar statystycznych do analizy szerokiej adaptacji odmian mi.: miara nadrzędności plonowania $P_{i}$ [Lin, Binns 1988], miara niezawodności przewagi plonowania $R_{i}$ [Eskridge, Mumm 1992], miara stabilności Kanga $Y S_{i}$ [Kang 1993]. Obok stabilności, szeroka adaptacja odmiany do określonych warunków wydaje się być ważnym atrybutem rolniczym gatunków uprawnych, dlatego wymaga poszukiwania jak najlepszych metod jej oceny. Wykorzystania powyższych metod nie odnajduje się $\mathrm{w}$ literaturze związanej $\mathrm{z}$ cechami ziemniaka, w związku z czym podjęto próbę zastosowania ich i oceny w niniejszej pracy.

Celem badań była ocena stabilności rolniczej i stopnia szerokiej adaptacji plonu ogólnego bulw odmian ziemniaka uprawianych $\mathrm{w}$ zróżnicowanych warunkach pogodowych analizowanych lat, $\mathrm{z}$ zastosowaniem modelu AMMI, miary nadrzędności plonowania $P_{i}$, miary niezawodności przewagi plonowania $R_{i}$ i miary stabilności Kanga $Y S_{i}$ Warunki pogodowe analizowanych lat traktowano jako środowiska (środowisko $=$ rok).

\section{Materiały i Metody \\ Badania polowe}

Badania przeprowadzono w latach 20142017 w centralnej Polsce, w IHAR-PIB Oddział
W Jadwisinie $\left(52^{\circ} 45^{\prime} \mathrm{N}, 21^{\circ} 63^{\prime} \mathrm{E}\right)$. W badaniu uwzględniono 23 odmiany jadalne ziemniaka oraz 11 odmian skrobiowych należących do różnych grup wczesności (tab. 1). W poszczególnych latach badań uprawiano różną liczbę odmian, od 31 do 33. Wszystkie badane odmiany były wpisane do Krajowego Rejestru Odmian Ziemniaka, dwie $\mathrm{z}$ analizowanych odmian Mondeo i Syrena zostały wykreślone $\mathrm{z}$ rejestru w 2018 roku [Nowacki i in. 2019]

Doświadczenia zakładano metodą losowanych bloków w trzech powtórzeniach. Badania przeprowadzono na glebie lekkiej, o składzie granulometrycznym piasku gliniastego [PTG 2009]. Gleba w poszczególnych latach badań charakteryzowała się odczynem kwaśnym, wysoką zasobnością w przyswajalny fosfor, średnią $\mathrm{w}$ potas i średnią do niskiej w magnez (tab. 2).

Nawożenie organiczne pod ziemniaki stanowiła słoma pszenna $\mathrm{w}$ dawce $4-5 \mathrm{t} \cdot \mathrm{ha}^{-1}$ przyorywana po żniwach podorywką z dodatkiem azotu mineralnego (1 kg N na $100 \mathrm{~kg}$ słomy) oraz zielona masa międzyplonu ścierniskowego z gorczycy białej w dawce 15-16 t ha $^{-1}$ przyorywana jesienią orką przedzimową. Nawożenie mineralne fosforem i potasem stosowano w oparciu o zasobność gleby w przyswajalne formy tych składników. Każdego roku jesienią przed wykonaniem orki przedzimowej stosowano $17,5 \mathrm{~kg} \mathrm{P} \cdot \mathrm{ha}^{-1}$ (superfosfat wzbogacony 17,4\% P) i 99,6 kg K·ha ${ }^{-1}$ (sól potasowa - 49,8\% K). Nawożenie mineralne azotem (saletrzak $-27 \% \mathrm{~N}$ ) stosowano wiosną bezpośrednio przed sadzeniem bulw do dawki $100 \mathrm{~kg} \mathrm{~N} \cdot \mathrm{ha}^{-1}$. Chwasty niszczono stosując do wschodów roślin ziemniaka dwukrotnie obsypnik z łańcuchami. Bezpośrednio przed wschodami, po ostatnim obredleniu, zastosowano Linurex $500 \mathrm{SC}$ w dawce $2 \mathrm{l} \cdot \mathrm{ha}^{-1}$, a po wschodach roślin ziemniaka Titus $25 \mathrm{WG}$ w dawce $60 \mathrm{~g}$ ha $^{-1}$. W okresie wegetacji 4 krotnie przeprowadzano zabiegi ochronne przeciwko zarazie ziemniaka $\left(2\right.$ x Ridomil Gold MZ 67,8 WG - 2,5 kg $\cdot \mathrm{ha}^{-1}$; Pyton Consento $450 \mathrm{SC}-21 \cdot \mathrm{ha}^{-1}$; Revus $250 \mathrm{SC}$ $-0,61 \cdot \mathrm{ha}^{-1}$ ) oraz 3 krotnie zwalczające stonkę ziemniaczaną (Actara $25 \mathrm{WG}-70 \mathrm{~g} \cdot \mathrm{ha}^{-1}$; Apacz $50 \mathrm{WG}$ $-40 \mathrm{~g} \cdot \mathrm{ha}^{-1}$; SpinTor $240 \mathrm{SC}-0,151 \cdot \mathrm{ha}^{-1}$ ). Ziemniaki sadzono ręcznie w III dekadzie kwietnia w rozstawie $75 \times 33 \mathrm{~cm}$, a zbierano w III dekadzie września. Powierzchnia poletka wynosiła $14,85 \mathrm{~m}^{2}$, a liczba roślin do zbioru 60. Zbiory bulw przeprowadzano po uzyskaniu pełni dojrzałości roślin, w fazie rozwoju 97-99 w skali BBCH (Biologische Bundesanstalt, Bundessortenamt and Chemical Industry) [Klingauf 2001; Bleinholder i in. 2005]. Podczas zbiorów oceniano wielkość uzyskanego plonu 
Lista odmian ziemniaka uwzględnionych w doświadczeniu

List of potato cultivars chosen for the investigatio

\begin{tabular}{|c|c|c|c|c|c|}
\hline $\begin{array}{l}\text { Odmiana } \\
\text { Cultivar }\end{array}$ & $\begin{array}{l}\text { Grupa wczesności } \\
\text { Maturity grup }\end{array}$ & $\begin{array}{l}\text { Użytkowanie } \\
\text { Use }\end{array}$ & $\begin{array}{c}\text { Rok rejestracji } \\
\text { Year of registration }\end{array}$ & $\begin{array}{l}\text { Właściciel/hdowca } \\
\text { Owner/breeder }\end{array}$ & $\begin{array}{c}\text { Kraj } \\
\text { Country }\end{array}$ \\
\hline Denar & \multirow{6}{*}{$\begin{array}{l}\text { bardzo wczesne } \\
\text { very early }\end{array}$} & jadalne/table & 1999 & HZ Zamarte & PL \\
\hline Impalla & & jadalne/table & 2003 & Agrico & NL \\
\hline Lord & & jadalne/table & 1999 & HZ Zamarte & PL \\
\hline Miłek & & jadalne/table & 2006 & HZ Zamarte & PL \\
\hline Riviera & & jadalne/table & 1999 & Europlant & $\mathrm{DE}$ \\
\hline Viviana & & jadalne/table & 2010 & Europlant & $\mathrm{DE}$ \\
\hline Altesse & \multirow{7}{*}{$\begin{array}{l}\text { wczesne } \\
\text { early }\end{array}$} & jadalne/table & 2009 & PMHZ Strzekęcino & PL \\
\hline Bellarosa & & jadalne/table & 2006 & Europlant & $\mathrm{DE}$ \\
\hline Gwiazda & & jadalne/table & 2011 & HZ Zamarte & PL \\
\hline Ignacy & & jadalne/table & 2012 & PMHZ Strzekęcino & PL \\
\hline Michalina & & jadalne/table & 2010 & HZ Zamarte & PL \\
\hline Owacja & & jadalne/table & 2006 & PMHZ Strzekęcino & PL \\
\hline Vineta & & jadalne/table & 1999 & Europlant & DE \\
\hline Boryna & \multirow{14}{*}{$\begin{array}{l}\text { średnio wczesne } \\
\text { medium early }\end{array}$} & skrobiowe/starch & 2012 & PMHZ Strzekęcino & PL \\
\hline Finezja & & jadalne/table & 2007 & HZ Zamarte & PL \\
\hline Glada & & skrobiowe/starch & 1994 & PMHZ Strzekęcino & PL \\
\hline Harpun & & skrobiowe/starch & 1993 & PMHZ Strzekęcino & PL \\
\hline Honorata & & jadalne/table & 2012 & Europlant & $\mathrm{DE}$ \\
\hline Jubilat & & skrobiowe/starch & 2011 & PMHZ Strzekęcino & PL \\
\hline Kaszub & & skrobiowe/starch & 2012 & PMHZ Strzekęcino & PL \\
\hline Laskara & & jadalne/table & 2013 & PMHZ Strzekęcino & PL \\
\hline Malaga & & jadalne/table & 2013 & HZ Zamarte & PL \\
\hline Oberon & & jadalne/table & 2012 & HZ Zamarte & PL \\
\hline Pasat & & skrobiowe/starch & 2002 & PMHZ Strzekęcino & PL \\
\hline Satina & & jadalne/table & 2000 & Solana & $\mathrm{DE}$ \\
\hline Tajfun & & jadalne/table & 2004 & PMHZ Strzekęcino & PL \\
\hline Zuzanna & & skrobiowe/starch & 2012 & Europlant & $\mathrm{DE}$ \\
\hline Jelly & \multirow{4}{*}{$\begin{array}{l}\text { średnio późne } \\
\text { medium late }\end{array}$} & jadalne/table & 2005 & Europlant & $\mathrm{DE}$ \\
\hline Mondeo & & jadalne/table & 2013 & KWS & NL \\
\hline $\begin{array}{l}\text { Pasja Po- } \\
\text { morska }\end{array}$ & & jadalne/table & 2010 & PMHZ Strzekęcino & PL \\
\hline Syrena & & skrobiowe/starch & 2002 & PMHZ Strzekęcino & PL \\
\hline Hinga & \multirow{3}{*}{$\begin{array}{l}\text { późne } \\
\text { late }\end{array}$} & skrobiowe/starch & 1996 & PMHZ Strzekęcino & PL \\
\hline Inwestor & & skrobiowe/starch & 2005 & PMHZ Strzekęcino & PL \\
\hline Kuras & & skrobiowe/starch & 2007 & Agrico & NL \\
\hline
\end{tabular}

Tabela 2

Table 2

Zawartość przyswajanych form P, K, Mg w glebie oraz pH gleby

Soil content available form of $\mathrm{P}, \mathrm{K}, \mathrm{Mg}$ and $\mathrm{pH}$

\begin{tabular}{ccccc}
\hline \multirow{2}{*}{$\begin{array}{c}\text { Rok } \\
\text { Year }\end{array}$} & $\begin{array}{c}\mathrm{pH} \mathrm{w} \mathrm{KCl} \\
\mathrm{pH} \mathrm{in} \mathrm{KCl}\end{array}$ & \multicolumn{3}{c}{$\begin{array}{c}\text { Zawartość w glebie }\left(\mathrm{mg} \cdot \mathrm{kg}^{-1}\right) \\
\text { Content in the soil }\left(\mathrm{mg} \mathrm{kg}^{-1}\right)\end{array}$} \\
\cline { 3 - 5 } 2014 & 5,0 & $\mathrm{P}$ & $\mathrm{K}$ & $\mathrm{Mg}$ \\
2015 & 5,3 & 75 & 120 & 34 \\
2016 & 5,3 & 90 & 108 & 33 \\
2017 & 4,5 & 81 & 112 & 33 \\
\hline
\end{tabular}


ogólnego bulw z każdego poletka według metodyki opracowanej w IHAR [Roztropowicz 1999]. Zbiory wykonywano ręcznie.

\section{Warunki meteorologiczne}

Warunki meteorologiczne podczas realizacji badań monitorowano przy pomocy Stacji Meteorologicznej Campbell (Campbell Scientific Inc.) zlokalizowanej około $4 \mathrm{~km}$ od doświadczeń polowych. Rozpatrywano sumę opadów oraz średnią temperaturę powietrza podczas wegetacji roślin ziemniaka $\mathrm{w}$ miesiącach od kwietnia do końca września. W celu dokładnego scharakteryzowania warunków termiczno-wilgotnościowych w latach badań, obliczono współczynnik hydrotermiczny Sielianinowa, na podstawie sumy średnich dobowych temperatur i sumy opadów atmosferycznych dla każdego miesiąca [Skowera i in. 2014].

Lata badań: 2014, 2016, 2017 były ciepłe i wilgotne, o czym świadczyły wartości współczynnika hydrotermicznego Sielianinowa dla okresów wegetacji. Natomiast rok 2015 można określić jako ciepły i suchy. Rozkład opadów w poszczególnych miesiącach wegetacji był nierównomierny. W roku 2014 nadmiar opadów wystąpił w kwietniu, czerwcu i sierpniu, w maju notowano dostateczną ich ilość, natomiast w lipcu i wrześniu niedobór. W roku 2015 nadmiar opadów zanotowano w kwietniu, w maju i w lipcu była dostateczna ich ilość, natomiast niedobór opadów zanotowano w czerwcu i we wrześniu. Cały okres wegetacji ziemniaka w roku 2016 charakteryzował się nadmiarem opadów, tylko we wrześniu obserwowano ich niedobór. W 2017 roku w kwietniu i maju był znaczny niedobór opadów, natomiast pozostałe miesiące wegetacji charakteryzowały się nadmiarem opadów. Najwyższe średnie temperatury zanotowano w lipcu 2014 roku i sierpniu 2015 roku (tab.3)

\section{Analizy statystyczne}

Wyniki badań poddano analizie statystycznej. W procesie analizy wykorzystano średnie nie obciążone ilością obserwacji (ang. unbiased).

Sumy opadów i średnia temperatura powietrza w latach 2014-2017

Sums of atmospheric precipitation, average air temperatures in four growing seasons

\begin{tabular}{|c|c|c|c|c|c|c|c|}
\hline \multirow{3}{*}{$\begin{array}{l}\text { Rok/miesiąc } \\
\text { Year/month }\end{array}$} & \multicolumn{7}{|c|}{ Suma opadów (mm) } \\
\hline & \multicolumn{7}{|c|}{ Sum of rainfall $(\mathrm{mm})$} \\
\hline & IV & $\mathrm{V}$ & VI & VII & VIII & IX & IV-IX \\
\hline 2014 & 10,3 & 14,1 & 15,8 & 21,4 & 18,3 & 14,7 & 15,8 \\
\hline 2015 & 8,3 & 12,9 & 17,5 & 19,6 & 22,5 & 15,1 & 16,0 \\
\hline 2016 & 9,3 & 15,3 & 18,7 & 19,6 & 18,4 & 15,7 & 16,2 \\
\hline 2017 & 7,3 & 14,1 & 18,1 & 18,4 & 19,4 & 13,8 & 15,2 \\
\hline \multicolumn{8}{|c|}{ Średnia temperatura powietrza $\left({ }^{\circ} \mathrm{C}\right)$} \\
\hline \multicolumn{8}{|c|}{ Mean air temperature $\left({ }^{\circ} \mathrm{C}\right)$} \\
\hline 2014 & 61,1 & 41,3 & 69,8 & 23,5 & 79,2 & 11,9 & 286,8 \\
\hline 2015 & 27,8 & 39,5 & 15,4 & 62,6 & 8,6 & 36,6 & 190,5 \\
\hline 2016 & 31,4 & 92,2 & 85,4 & 103,6 & 61,4 & 9,5 & 383,5 \\
\hline 2017 & 8,9 & 10,1 & 107,5 & 78,8 & 57,0 & 140,8 & 403,1 \\
\hline \multicolumn{8}{|c|}{ Współczynnik hydrotermiczny Sielianinowa (K) } \\
\hline \multicolumn{8}{|c|}{ Selianinov's hydrotermal Coefficient (K) } \\
\hline 2014 & 2,0 & 0,9 & 1,5 & 0,4 & 1,4 & 0,3 & 1,1 \\
\hline 2015 & 1,1 & 1,0 & 0,3 & 1,0 & 0,1 & 0,8 & 0,7 \\
\hline 2016 & 1,1 & 1,9 & 1,5 & 1,7 & 1,1 & 0,2 & 1,3 \\
\hline 2017 & 0,4 & 0,2 & 2,0 & 1,4 & 1,0 & 3,4 & 1,4 \\
\hline
\end{tabular}


Ze względu na braki w obserwacjach wielkości plonu odmian ziemniaka (dane nieortogonalne), analizę AMMI przeprowadzono w dwuetapowym podejściu. W pierwszym etapie analizowano wyniki z każdego roku oddzielnie. W drugim etapie przeprowadzono analizę łączną (ang. combined analysis) na podstawie średnich z pierwszego etapu.

Dla każdej zmiennej wykonano analizę wariancji, następnie wykonano analizę interakcji genotyp $\times$ środowisko (rok) $\mathrm{z}$ zastosowaniem modelu AMMI. Szczegółowej interpretacji poddano ocenę istotności składowych addytywnych i multiplikatywnych modelu. Wykonano biploty, pierwszy dla średnich genotypowych i środowiskowych względem składowej środowiskowej IPC(1), drugi dla dwóch pierwszych składowych środowiskowych IPC (1) i IPC (2). Na podstawie pierwszego biplotu oceniono rodzaj i wielkości efektu interakcyjnego dla poszczególnych genotypów i środowisk (lat). Na podstawie drugiego biplotu określono efekt interakcji pod kątem stabilności plonowania badanych odmian oraz wskazano genotypy, które charakteryzowały się relatywnie wysokim plonem w roku badań o określonych warunkach termiczno -wilgotnościowych (wskazano genotypy o wąskiej, lokalnej adaptacji) [Annicchiarico 2002; Kaya i in. 2006].

Ocenę adaptacji badanych odmian przeprowadzono na podstawie dwóch ilościowych miar i porządkowej miary stopnia szerokiej adaptacji odmiany [Iwańska i in. 2008, 2009; Mądry i Iwańska $2011 \mathrm{a}, \mathrm{b}] \mathrm{tj}$. :

- miary nadrzędności plonowania i-tej odmiany $P_{i}$ [Lin i Binns 1988],

- miary niezawodności przewagi plonowania i-tej odmiany $R_{i}$ [Eskridge i Mumm 1992],

- miary Kanga średniego plonu i jego stabilności $Y S_{i}$ [Kang 1993].

Obliczenia statystyczne wykonano w programie Statistica 13.3 [TIBCO Software Inc., 2017] $\mathrm{z}$ dodatkiem Zestaw przyrodnika w wersji 1.0 [StatSoft Polska Sp. z o. o. 2018].

\section{Wyniki}

Wartości ocenianej cechy różniły się pomiędzy badanymi odmianami oraz latami badań. W tabeli 4 przedstawiono średnie wartości plonu ogólnego bulw ocenianych odmian ziemniaka w czterech latach.

Najwyższy średni plon ogólny odmian ziemniaka uzyskano w 2016 roku, natomiast najniższy w 2015 roku (tab. 4). Średnio dla czterech lat badań najwyżej plonowały odmiany: Mondeo, Michalina, Ignacy, Gwiazda.
$\mathrm{Na}$ podstawie analizy wariancji wg. modelu AMMI stwierdzono, że wielkość plonu ogólnego ziemniaka w największym stopniu zależała od roku $(58,6 \%)$, następnie od odmiany $(17,0 \%)$ oraz od interakcji odmiana $\times$ rok (środowisko) $(15,0 \%)$ (tab. 5). Stwierdzono, istotność wszystkich składowych interakcyjnych (IPC1, IPC2, IPC3). Udział w zmienności interakcji wynosił $61,8 \%$ dla IPC(1), $20,3 \%$ dla IPC(2) oraz 13,9\% dla IPC(3). Dwie pierwsze składowe (IPC1 i IPC2) odpowiadały łącznie za $82,1 \%$ całego efektu interakcyjnego.

Na podstawie analizy wykresu średnich plonowania względem IPC1 stwierdzono, największy dodatni efekt interakcyjny u odmiany Kuras, która reagowała relatywnie wyższymi plonami w latach o korzystnych warunkach pogodowych (rys. 1a). Największy ujemny efekt interakcyjny stwierdzono dla odmian Michalina, Gwiazda i Ignacy, które plonowały relatywnie lepiej podczas występowania słabszych warunków pogodowych. Efekty bliskie 0 uzyskano dla genotypów: Miłek, Jelly, Mondeo, Zuzanna, Pasat, Riviera i Syrena, co jest potwierdzeniem stabilności tych odmian pod względem plonowania. Najwyższy efekt główny otrzymano dla odmian: Mondeo, Michalina, Ignacy, Gwiazda. Były to odmiany, które uzyskały w analizowanych latach plony wyższe niż przeciętne. Odmianami o najniższym efekcie głównym (najniższym przeciętnym plonowaniu) były Pasja Pomorska i Glada.

Analiza biplotu dla dwóch pierwszych składowych interakcyjnych: IPC(1) i IPC(2) pozwoliła na wskazanie odmian o wysokiej adaptacji do konkretnych warunków w analizowanych latach (rys. 1b). Odmiany: Denar, Zuzanna, Harpun, Finezja i Malaga plonowały najwyżej w latach 2014 i 2015. Warunki termiczno-wilgotnościowe panujące w roku 2016 sprzyjały plonowaniu odmian Zuzanna, Syrena, Miłek oraz Altesse. Natomiast w warunkach występujących w 2017 roku najwyższe plony uzyskano u odmian Hinga, Pasja Pomorska, Oberon, Zuzanna oraz Lord.

W tabeli 6 przedstawiono miary stopnia szerokiej adaptacji dla odmian ziemniaka objętych badaniami. Pierwszą rozpatrywaną miarą szerokiej adaptacji była miara nadrzędności plonowania $P_{i}$. Im wartość tej miary jest bliższa zeru tym odmiana posiada wyższy stopień szerokiej adaptacji. Kolejnym badanym parametrem była miara niezawodności plonowania odmiany $R_{i}$, która wyrażała prawdopodobieństwo plonowania danej odmiany powyżej średniej środowiskowej. Odmiana dla której $R_{i}$ przyjmuje wartość 1 , plonuje powyżej średniej środowiskowej dla całego badanego okresu, zatem taka odmiana wykazuje najwyższy 
Średnie wartości plonu ogólnego bulw $\left(t^{\cdot} \cdot h^{-1}\right)$ w latach badań

Table 4

\section{Mean values of total tuber yield $\left(\mathrm{t}^{\cdot} \mathrm{ha}^{-1}\right)$ in years of research}

\begin{tabular}{|c|c|c|c|c|c|c|c|c|c|c|}
\hline \multirow{2}{*}{$\begin{array}{l}\text { Odmiana } \\
\text { Cultivar }\end{array}$} & \multicolumn{4}{|c|}{$\begin{array}{l}\text { Poln ogólny }\left(\mathrm{t} \cdot \mathrm{ha}^{-1}\right) \\
\text { Total tuber field }\left(\mathrm{t} \cdot \mathrm{ha}^{-1}\right)\end{array}$} & \multirow{2}{*}{$\begin{array}{l}\text { Średnia } \\
\text { Mean }\end{array}$} & \multicolumn{5}{|c|}{$\begin{array}{l}\text { Odchylenie standardowe } \\
\text { Standard deviation }\end{array}$} \\
\hline & 2014 & 2015 & 2016 & 2017 & & 2014 & 2015 & 2016 & 2017 & 2014-2017 \\
\hline Denar & 54,97 & 31,4 & 71,6 & 55,23 & 53,3 & 4,32 & 3,74 & 3,99 & 0,83 & 14,49 \\
\hline Impalla & 49,87 & 25,2 & 57,53 & 52,33 & 46,23 & 3,61 & 5,8 & 4,14 & 1,19 & 13,46 \\
\hline Lord & 55,3 & 30,47 & 67,63 & 58,73 & 53,03 & 3,89 & 3,7 & 6,88 & 3,09 & 14,93 \\
\hline Miłek & 48,9 & 27,3 & 48,27 & 41,1 & 41,39 & 3,41 & 3,96 & 3,62 & 2 & 9,52 \\
\hline Riviera & $-*$ & 26,3 & 48,33 & 47,07 & 40,57 & - & 6,14 & 6,68 & 4,04 & 11,57 \\
\hline Viviana & 54,6 & 19,93 & 59,5 & 47,7 & 45,43 & 5,88 & 2,81 & 17,12 & 3,16 & 17,85 \\
\hline Altesse & 44,43 & 31,87 & 69,6 & 47,4 & 48,33 & 0,83 & 0,92 & 3,61 & 6,15 & 14,53 \\
\hline Bellarosa & 34,57 & 23,87 & 60,6 & 48,47 & 41,88 & 1,98 & 3,06 & 2,16 & 2,31 & 14,65 \\
\hline Gwiazda & 54,13 & 31,03 & 73,4 & 64,47 & 55,76 & 2,02 & 2,21 & 7,08 & 3,04 & 16,9 \\
\hline Ignacy & 56,33 & 29,4 & 80,07 & 59,93 & 56,43 & 2,56 & 1,05 & 7,54 & 4,01 & 19,23 \\
\hline Michalina & 53,57 & 31,57 & 78,3 & 68,17 & 57,9 & 1,8 & 2,39 & 4,02 & 4,21 & 18,56 \\
\hline Owacja & 50,53 & 28,17 & 67,17 & 55,1 & 50,24 & 1,22 & 5,12 & 7,14 & 8,4 & 15,64 \\
\hline Vineta & 39,47 & 28,73 & 67,47 & 48,73 & 46,1 & 2,49 & 3,29 & 5,81 & 6,07 & 15,38 \\
\hline Boryna & - & 33,67 & 50,57 & 36,37 & 40,2 & - & 7,12 & 2,51 & 2,54 & 8,82 \\
\hline Finezja & 45,8 & 36,7 & 59,47 & 41,7 & 45,92 & 3,02 & 7 & 5,82 & 9,66 & 10,58 \\
\hline Glada & 42,07 & 29,17 & - & 37,3 & 36,18 & 2,02 & 8,65 & - & 4,35 & 7,51 \\
\hline Harpun & 42,67 & 25,13 & 52 & 33,87 & 38,42 & 0,68 & 4,94 & 3,49 & 2,51 & 10,81 \\
\hline Honorata & 49,3 & 39 & 55,23 & - & 47,84 & 4,2 & 3,91 & 4,41 & - & 7,98 \\
\hline Jubilat & 48,87 & 31,37 & 59,2 & 30,8 & 42,56 & 1,1 & 9,07 & 2,56 & 13,35 & 14,39 \\
\hline Kaszub & 41,53 & 33,27 & 49,23 & 32,73 & 39,19 & 2,41 & 2,85 & 3,49 & 6,25 & 7,86 \\
\hline Laskara & - & 28,63 & 69,97 & 48,37 & 48,99 & - & 7,72 & 7,5 & 7,05 & 19,03 \\
\hline Malaga & 52,53 & 31,23 & - & 38,1 & 40,62 & 3,27 & 6,36 & - & 4,49 & 10,32 \\
\hline Oberon & 54,57 & 47 & 67,73 & 43,4 & 51,6 & 2,47 & 6,64 & 12,89 & 7,36 & 13,17 \\
\hline Pasat & 46,9 & - & 55,37 & 49,43 & 50,57 & 1,21 & - & 2,85 & 5,68 & 4,97 \\
\hline Satina & 55,77 & 40,83 & 70,43 & 43,47 & 52,63 & 2,25 & 5,16 & 8,44 & 3,85 & 13,09 \\
\hline Tajfun & 51,7 & 44,17 & 55,83 & 45,2 & 49,23 & 2,68 & 3,91 & 4,25 & 5,83 & 6,21 \\
\hline Zuzanna & 39,77 & 29,87 & 59,17 & 41,8 & 42,65 & 1,13 & 6,98 & 2,91 & 11,21 & 12,45 \\
\hline Jelly & 45,63 & 34,3 & 69,8 & 38,23 & 46,99 & 2,1 & 7,9 & 3,34 & 8,36 & 15,3 \\
\hline Mondeo & 56,6 & 49,83 & 72,63 & - & 59,69 & 0,72 & 10,32 & 2,65 & - & 11,46 \\
\hline Pasja Pomorska & 44,67 & 26,73 & 54,2 & 24,17 & 37,44 & 0,92 & 5,3 & 5,73 & 3,04 & 13,53 \\
\hline Syrena & 51,47 & 34,8 & 68,9 & - & 51,72 & 3,18 & 8,79 & 2,55 & - & 15,54 \\
\hline Hinga & 46,43 & 29,73 & 56,1 & 28,6 & 40,22 & 1,71 & 4,95 & 6,32 & 6,81 & 12,92 \\
\hline Inwestor & 40,5 & 25,9 & 55,37 & 32,2 & 38,49 & 1,21 & 7,83 & 4,27 & 2,45 & 12,19 \\
\hline Kuras & 44,37 & 39,93 & 55,7 & 30,53 & 42,63 & 0,63 & 7,32 & 4,75 & 6,87 & 10,58 \\
\hline Średnia / Mean & 48,32 & 32,02 & 62,07 & 44,22 & $\mathrm{x}$ & 6,23 & 7,86 & 10,16 & 11,86 & $\mathrm{x}$ \\
\hline
\end{tabular}


Zestawienie wyników analizy wariancji dla analizowanych odmian ziemniaka w czterech latach badań Comparison of the variance analysis results for analyzed potato varieties in four years of research

\begin{tabular}{cccccc}
\hline $\begin{array}{c}\text { Efekty } \\
\text { Efects }\end{array}$ & DS & MS & $\begin{array}{c}\text { Procent zmienności } \\
\text { Precent of variability }\end{array}$ & F & $\begin{array}{c}\text { wartość p } \\
\text { p-value }\end{array}$ \\
\hline $\begin{array}{c}\text { Ogół Total } \\
\text { Rok Year }\end{array}$ & 380 & 203,7 & 100 & 51,62 & 0,000 \\
Bloki w latach & 8 & 293,2 & 58,6 & 14,69 & 0,000 \\
Blocks in year & 33 & 399,2 & 3,0 & 20,00 & 0,000 \\
Odmiana Cultivar & 15133,0 & 17,0 & 6,44 & 0,000 \\
$\begin{array}{l}\text { Odmiana } \times \text { rok } \\
\text { Cultivar } \times \text { year }\end{array}$ & 90 & 128,7 & 15,0 & 6,44 & 0,000 \\
IPC 1 & 35 & 204,3 & $9,2(61,8)^{*}$ & 4,03 & 0,000 \\
IPC 2 & 33 & 71,2 & $3,0(20,3)$ & 4,73 & 0,000 \\
IPC 3 & 22 & 73,3 & $2,1(13,9)$ & & \\
Błąd Error & 246 & 20,0 & 6,3 & & \\
\hline
\end{tabular}

*-procentowy udziat $w$ zmienności interakcji
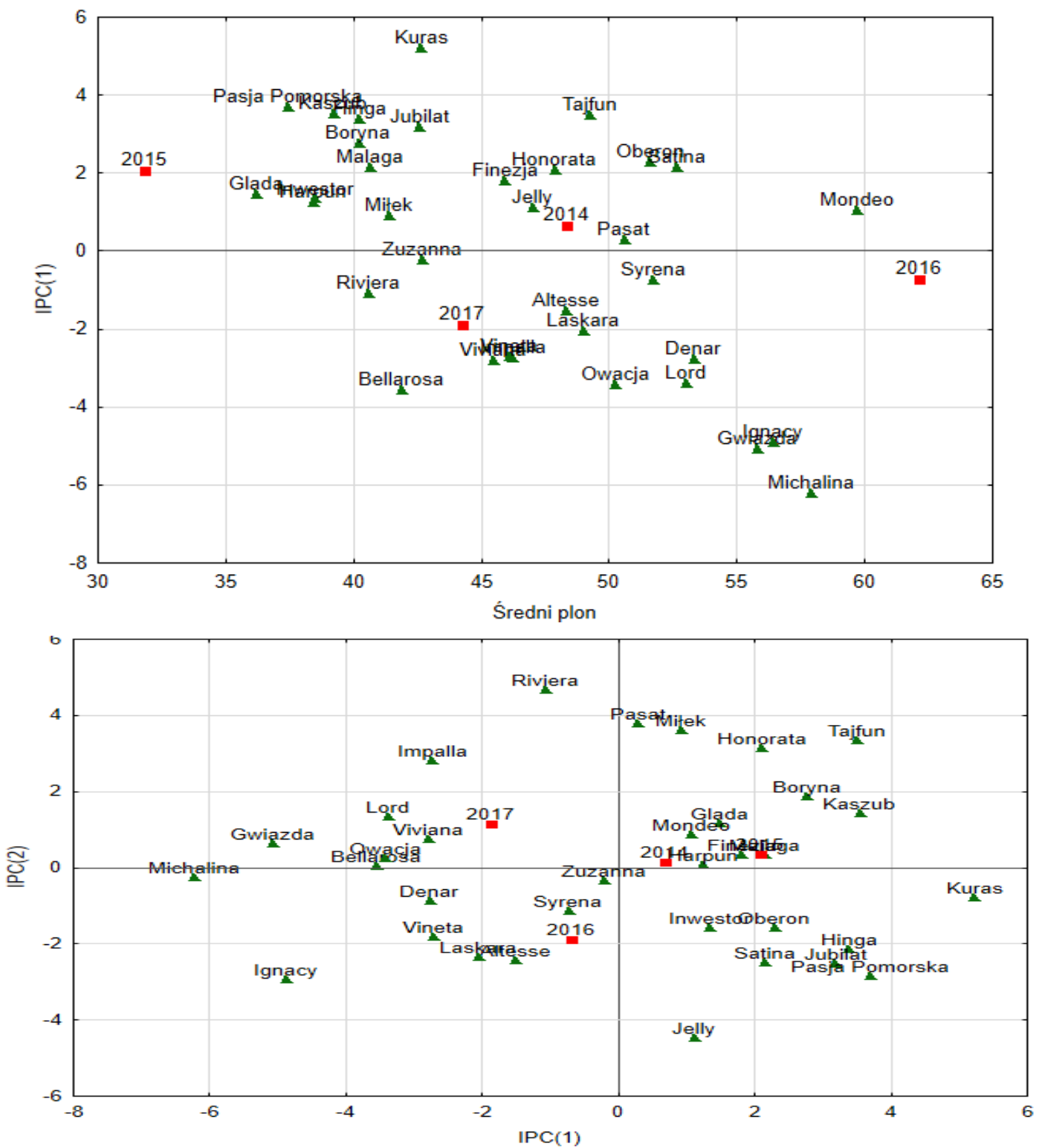

Rys. 1. Biploty uzyskane w analizie AMMI dla plonu bulw a) IPC (1)/średni plon bulw; b) IPC (1)/IPC (2)

Fig. 1. Biplots from AMMI analysis for tuber yield: a) IPC (1)/mean tuber yield; b) IPC (1)/IPC (2) 
Tabela 6

Table 6

Zestawienie miar szerokiej adaptacji dla plonu ogólnego

Wide adaptation degree estimation for total tuber yield

\begin{tabular}{|c|c|c|c|}
\hline $\begin{array}{l}\text { Odmiana } \\
\text { Cultivar }\end{array}$ & $\begin{array}{c}\text { Miara nadrzędności plonowa- } \\
\text { nia } P_{i} \\
\text { Superiority measure } P_{i}\end{array}$ & $\begin{array}{c}\text { Miara niezawodności przewagi } \\
\text { plonowania } R_{i} \\
\text { Eskridey's yield reliability } \\
\text { measure }\end{array}$ & $\begin{array}{l}\text { Miara stabilności } \\
\text { Kanga } Y S_{i} \\
\text { Kang's stability } \\
\text { measure } Y S_{i}\end{array}$ \\
\hline Altesse & 126 & 0,75 & 22 \\
\hline Bellarosa & 241 & 0,25 & 10 \\
\hline Boryna & 357 & 0,33 & 5 \\
\hline Denar & 73 & 0,75 & 31 \\
\hline Finezja & 177 & 0,25 & 15 \\
\hline Glada & 265 & 0,00 & -1 \\
\hline Gwiazda & 52 & 0,75 & 33 \\
\hline Harpun & 346 & 0,00 & 2 \\
\hline Hinga & 331 & 0,00 & 6 \\
\hline Honorata & 131 & 0,67 & 21 \\
\hline Ignacy & 61 & 0,75 & 34 \\
\hline Impalla & 176 & 0,50 & 17 \\
\hline Inwestor & 342 & 0,00 & 3 \\
\hline Jelly & 170 & 0,50 & 20 \\
\hline Jubilat & 279 & 0,25 & 11 \\
\hline Kaszub & 338 & 0,25 & 4 \\
\hline Kuras & 282 & 0,25 & 12 \\
\hline Laskara & 157 & 0,67 & 23 \\
\hline Lord & 78 & 0,75 & 30 \\
\hline Malaga & 211 & 0,33 & 8 \\
\hline Michalina & 43 & 0,75 & 31 \\
\hline Miłek & 289 & 0,25 & 9 \\
\hline Mondeo & 9 & 1,00 & 36 \\
\hline Oberon & 107 & 0,75 & 27 \\
\hline Owacja & 105 & 0,75 & 25 \\
\hline Pasat & 176 & 0,33 & 26 \\
\hline $\begin{array}{l}\text { Pasja Pomor- } \\
\text { ska }\end{array}$ & 410 & 0,00 & 1 \\
\hline Riviera & 334 & 0,33 & 7 \\
\hline Satina & 98 & 0,75 & 29 \\
\hline Syrena & 63 & 1,00 & 28 \\
\hline Tajfun & 146 & 0,75 & 24 \\
\hline Vineta & 159 & 0,50 & 16 \\
\hline Viviana & 217 & 0,50 & 14 \\
\hline Zuzanna & 227 & 0,00 & 13 \\
\hline
\end{tabular}


możliwy stopień szerokiej adaptacji. Ostatnim badanym wskaźnikiem szerokiej adaptacji była miara Kanga $Y S_{\text {. }}$. Stanowi ona pewną funkcję ważoną rang zarówno dla średniej genotypowej plonu odmiany oraz wariancji stabilności. Im wyższa jest wartość $Y S_{i}$ dla odmiany tym wyższy jest jej stopień szerokiej adaptacji.

Stwierdzono że, największa zgodność uporządkowania odmian $\mathrm{w}$ rankingu miar szerokiej adaptacji występowała dla odmian o najwyższym stopniu szerokiej adaptacji. Odmiana Mondeo została zgodnie przyporządkowana na pierwsze miejsce $\mathrm{w}$ rankingu przez wszystkie trzy rozpatrywane miary stopnia szerokiej adaptacji (tab. 6). Zgodnie z miarą niezawodności plonowania odmiany $R_{i}$, odmiany Mondeo i Syrena cechowały się największym prawdopodobieństwem uzyskania plonów powyżej średniej środowiskowej. Według oceny Kanga $Y S_{i}$, za odmiany o najszerszym stopniu szerokiej adaptacji do warunków środowiska uznano: Mondeo, Ignacy, Gwiazda, Denar, Michalina i Lord.

\section{Dyskusja}

W niniejszej pracy przedstawiono ocenę plonu oraz wyniki analizy interakcji genotypowo-środowiskowej 34 odmian ziemniaka. Wykonano ją na podstawie cyklu czteroletniego doświadczenia polowego przeprowadzonego w Centralnej Polsce. Uznanie lat za zmienne środowiska jest możliwe, ponieważ każdy rok charakteryzują inne, odrębne warunki środowiskowe dla uprawianych roślin [Oleksiak i Mańkowski 2003]. Warunki klimatyczne panujące w latach badań mają duży wpływ na udział środowiska w interakcji GxE, a charakter i stopień interakcji w poszczególnych środowiskach zależy bardziej od warunków meteorologicznych panujących w danym roku niż od lokalizacji miejsca doświadczenia [Drzazga i Krajewski 2001; Wójtowicz 2013]. Wyniki badań własnych potwierdzają tę tezę. Warunki meteorologiczne miały ponad trzykrotnie większy wpływ na wielkość plonu ogólnego bulw, niż odmiana i interakcja genotyp x rok. Czynniki pogodowe najsilniej oddziaływały na wielkość plonu ogólnego bulw także w badaniach Kołodziejczyka [2013]. Wielkość plonu ogólnego i handlowego bulw w największym stopniu determinowane były warunkami meteorologicznymi w poszczególnych latach (ponad 76\% zmienności całkowitej). Właściwości odmianowe wyjaśniały 4,2\% zmienności, z kolei interakcja odmian z latami odpowiadała w 17,9\% za zmienność plonu ogólnego. Również w badaniach Sawickiej i Pszczółkowskiego [2004] warunki meteorologiczne wyjaśniały ponad $95 \%$ wariancji plonu ogólnego oraz handlowego bulw, właściwości odmian ponad 3\%, a interakcja tych czynników niespełna $1 \%$ całkowitej zmienności. Autorzy nie podają jednak udziału błędu doświadczenia, który może stanowić nawet ok. 50\% zmienności całkowitej [Bombik i Boligłowa 1994].

Najwyższy plon ogólny stwierdzono w 2016 roku, co było związane z korzystnym układem warunków meteorologicznych w okresie wegetacji roślin. Z badań Głuskiej [2004] wynika, że orientacyjne potrzeby wodne dla odmian wczesnych w okresie od maja do września wynoszą $300 \mathrm{~mm}$, a dla odmian późnych $362 \mathrm{~mm}$. Kowalik i Scalenghe [2009] twierdzą, że średnie zapotrzebowanie ziemniaka na wodę w Polsce wynosi $315 \mathrm{~mm}$ w sezonie wegetacyjnym. Według Kalbarczyków [2009], optymalne warunki pogodowe, sprzyjające uzyskaniu wysokich plonów to umiarkowana średnia temperatura powietrza w okresie maj-wrzesień (średnio $15,2^{\circ} \mathrm{C}$ ) i sumy opadów wynoszące około: $45 \mathrm{~mm}$ w maju, $65 \mathrm{~mm}$ w czerwcu, $90 \mathrm{~mm}$ w lipcu, $75 \mathrm{~mm}$ w sierpniu i $60 \mathrm{~mm}$ we wrześniu. Niedobór opadów i wysoka temperatura w 2015 wpłynęły na znaczne ograniczenie plonowania, o ok $50 \%$ w stosunku do 2016 roku. Inni badacze również wykazali wyraźny spadek plonów przy niedoborze opadów [Sawicka, Krochmal-Marczak 2005; Dzieżyc $i$ in. 2012].

Analiza interakcji genotyp $\times$ rok pozwoliła na wytypowanie odmian stabilnych rolniczo pod względem plonowania w zmiennych warunkach meteorologicznych w poszczególnych latach badań. Udowodniono, że siedem odmian nie wykazało interakcji ze środowiskiem i uznano je za stabilne rolniczo pod względem uzyskanego plonu. Były to odmiany: Miłek, Jelly, Mondeo, Zuzanna, Pasat, Riviera i Syrena. Pozostałe odmiany uznano za plonujące niestabilnie, podlegające silnym wpływom warunków środowiska. Odmiany te można by uznać za tzn. odmiany nieprzewidywalne [Mądry i in. 2010]. Jednak czteroletni okres badań jest zbyt krótki by móc w ten sposób ocenić odmianę. Wyniki badań własnych, podobnie jak w dwuletnich badaniach Flis i in. [2014] prowadzonych w trzech krajach, również wyłoniły odmianę Finezja jako niestabilną pod względem plonowania. Uzyskany wynik dotyczący odmiany Finezja był także zgodny z badaniami Rymuzy $i$ in. [2017], które realizowano $w$ trzech miejscowościach w Polsce w czterech latach badań.

Wyodrębniono odmiany o wysokim dodatnim efekcie głównym: Gwiazda, Ignacy, Michalina i Mondeo, czyli takie które plonowały wyżej 
niż średnia odmianowa (rys. 1a, tab. 4). Według Bombika i innych [2007], odmiany o wysokim dodatnim efekcie głównym mogą być rekomendowane do uprawy $\mathrm{w}$ zmiennych lub mniej sprzyjających warunkach uprawy. Wykazali oni, że zmienność plonu bulw ziemniaka determinowana była przez efekty interakcyjne lat $\mathrm{z}$ badanymi czynnikami i błąd doświadczenia.

Genotypy o szerokiej adaptacji to takie, które charakteryzują się uzyskiwaniem wyższych plonów niż średnia środowiskowa w znacznej większości badanych środowisk [Annicchiarico 2002; Tollenaar, Lee 2002]. Na podstawie badań stwierdzono, że spośród ocenianych odmian największa ich zgodność uporządkowania w rankingu miar szerokiej adaptacji pod względem plonowania dotyczyła odmian: Mondeo, Ignacy, Gwiazda, Denar, Michalina i Lord (tab. 6). Odmiany te odznaczały się zdolnością do gromadzenia plonu na wysokim poziomie $\mathrm{w}$ zmiennych warunkach meteorologiczno-glebowych (tab. 4).

Założenia oraz wyniki przeprowadzonego doświadczenia są zgodne $\mathrm{z}$ badaniami Loserta $i$ in. [2017] którzy stwierdzili, że trend plonowania odmian można zidentyfikować jedynie poprzez obserwacje plonów przez kilka sezonów wegetacyjnych. W grupie analizowanych odmian, wyróżniała się odmiana Mondeo, która była stabilna w sensie rolniczym oraz znajdowała się na pierwszym miejscu w rankingu miar szerokiej adaptacji względem plonowania. Odmiana Mondeo spełniła warunki genotypu idealnego [Kaya i in. 2006]. W praktyce rolniczej, a także w hodowli poszukuje się właśnie takich odmian - stabilnych pod względem plonowania, odznaczających się szeroką zdolnością adaptacyjną do zróżnicowanych warunków.

\section{Podsumowanie}

Interakcja genotyp $\times$ rok pozwoliła wskazać odmiany ziemniaka stabilne i niestabilne rolniczo pod względem plonowania. Oceniono reakcję tych odmian na zmienne warunki lat badań (środowisk) oraz ich adaptację do tych warunków. Zastosowane miary porządkujące tj. stopnia szerokiej adaptacji oraz miara ilościowa - stabilności Kanga, umożliwiły wykonanie rankingu odmian o relatywnie najwyższym (wśród badanych odmian) plonie ogólnym bulw.

Uzyskane wyniki badań odmianowych mogą być pomocne w pracach hodowlanych nad tworzeniem nowych genotypów ziemniaka oraz mogą ułatwić rolnikom wybór odmian stabilnych oraz o szerokiej bądź wąskiej adaptacji do warunków glebowo-klimatycznych gospodarstwa.

\section{Wnioski}

1. Wielkość plonu ogólnego bulw zależała istotnie od odmiany, warunków lat badań oraz interakcji odmiana $\mathrm{x}$ rok.

2. Udział interakcji odmiana $\mathrm{x}$ rok $\mathrm{w}$ zmienności ogólnej dla wielkości uzyskiwanego plonu wynosił $15 \%$.

3. Szczegółowa analiza AMMI pozwoliła stwierdzić, że odmiany Miłek, Jelly, Mondeo, Zuzanna, Pasat, Riviera i Syrena były stabilne rolniczo pod względem plonowania $\mathrm{w}$ badanych warunkach meteorologicznych.

4. Ocena stopnia szerokiej adaptacji odmian do warunków uprawy przeprowadzona za pomocą dwóch miar ilościowych i porządkowej miary Kanga, pozwoliła na stwierdzenie, że najwyższy stopień szerokiej adaptacji do warunków uprawy występujących w badanym okresie wykazały odmiany: Mondeo, Ignacy, Gwiazda, Denar, Michalina i Lord.

5. Pod względem plonowania odmianę Mondeo można określić jako odmianę idealną tzn. nie wykazującą interakcji ze środowiskiem, o szerokiej adaptacji do zróżnicowanych warunków meteorologicznych, charakteryzującą się najwyższym plonem ogólnym spośród porównywanych odmian.

\section{Literatura}

Annicchiarico, P. 2002. Genotype x environment interaction: challenges and opportunities for plant breeding and cultivar recommendations. Plant Production and Protection, Fao, Rome, (174), 85-86.

Becker H. C., Leon J. 1988. Stability Analysis in Plant Breeding. Plant Breeding, 101(1), 1-23. DOI: 10.1111/ j.1439-0523.1988.tb00261.x

Bleinholder H., Buhr L., Feller C., Hack H., Hess M., Klose R., Meier U., Stauss R., van den Boom T., Weber E., Lancashire P. D., Munger P. 2005. Compendium of Growth Stage Indentyfication Keys for Monoand Dicotyledonous Plants. Klucz do określania faz rozwojowych roślin jedno- i dwuliściennych w skali BBCH. Tłum. Adamczewski K., Matysiak K. Instytut Ochrony Roślin, 15-19, 28-33, 40-43.

Bombik A., Boligłowa E., 1994. Zmienność cech jakości ziemniaka jadalnego spowodowana nawożeniem dolistnym. Fragmenta Agronomica, 2, 52-57.

Bombik A., Stankiewicz C., Starczewski J. (2003). Interakcja genotypowo-środowiskowa $\mathrm{w}$ ocenie wybranych cech jakości ziemniaka . Biuletyn IHAR (226/227/2), 539-546.

Bombik A., Rymuza K., Markowska M., Stankiewicz C. 2007. Variability analysis of selected quantitative characteristics in edible potato varieties. Acta Scientiarum Polonorum. Agricultura, 6(3), 5-15. 
Caliński T. 1967. Model analizy wariancji dla doświadczeń wielokrotnych. Rocznik Nauk Rolniczych, Seria A(93), 549-579.

Dzieżyc H., Chmura K., Dmowski Z. 2012. Określenie wpływu warunków opadowych na plonowanie ziemniaka bardzo wczesnego i wczesnego w południowej Polsce. ITP Woda Środowisko Obszary Wiejskie, 12(3(38)), 133-141.

Drzazga T., Krajewski P., 2001. Zróżnicowanie środowisk pod względem stopnia interakcji w seriach doświadczeń z pszenicą ozimą. Biul. IHAR, 218/219, 111-115.

Eskridge K. M., Mumm R. F. 1992. Choosing plant cultivars based on the probability of outperforming a check. Theoretical and Applied Genetics, 84(3), 494-500. DOI: 10.1007/BF00229512

Flis B., Domański L., Zimnoch-Guzowska E., Polgar Z., Pousa S. Á., Pawlak A. 2014. Stability analysis of agronomic traits in potato cultivars of different origin. American Journal of Potato Research, 91(4), 404-413. DOI: 10.1007/s12230-013-9364-6

Flis B., Tatarowska B. 2019. Analiza interakcji genotypowo-środowiskowej w odniesieniu do wybranych cech użytkowych ziemniaka jadalnego $\mathrm{w}$ różnych systemach uprawy. Biuletyn IHAR, (286), 239-242.

Galek R., Bujak H., Kaczmarek J. 2000. Ocena stabilności cech bonitacyjnych i technologicznych w kolekcji żyta jarego na podstawie pięciu parametrów statystycznych. Biul. IHAR, (216), 69-76.

Głuska A. 2004. Wpływ zmiennego rozkładu opsdów na cechy bulw ziemniaka (Solanum tuberosum L.) oraz wyznaczenie okresu krytycznego wrażliwości na niedobór wody u odmian o różnej długości okresu wegetacji. Zeszyty Problemowe Postępów Nauk Rolniczych, (496), 217-227.

Iwańska M., Mądry W., Drzazga T., Rajfura A. 2008. Zastosowanie miar statystycznych do oceny stopnia szerokiej adaptacji odmian pszenicy ozimej na podstawie serii doświadczeń przedrejestrowych. Biul. IHAR 250: 67 $-86$.

Iwańska M., Mądry W., Rajfura A., Drzazga T. 2009. Porównanie syntetycznych wskaźników stopnia adaptacji odmian na przykładzie serii doświadczeń przedrejestrowych $\mathrm{z}$ pszenicą ozimą. Biul. IHAR 253: $31-45$.

Kalbarczyk R., Kalbarczyk E. 2009. Potrzeby i niedobory opadów atmosferycznych w uprawie ziemniaka średnio późnego i późnego w Polsce. Infrastruktura i Ekologia Terenów Wiejskich, (03), 129-140.

Kang M. S. 1993. Simultaneous selection for yield and stability in crop performance trials: Consequences for growers. Agronomy Journal, (85), 754-757.

Kaya Y., Akçura M., Taner S. 2006. GGE-Biplot Analysis of Multi-Environment Yield Trials in Bread Wheat. Turkish Journal of Agriculture and Forestry, 30(5),
$325-337$

Klingauf F. 2001. Growth stages of mono-and dicotyledonous plants. BBCH Monograph. (2. wyd.). Federal Biological Research Centre for Agriculture and Forestry,. Pobrano z http://www.jki.bund.de/fileadmin/dam_uploads/_veroeff/bbch/BBCH-Skala_englisch.pdf

Kołodziejczyk M. 2013. Fenotypowa zmienność plonowania, składu chemicznego oraz wybranych cech jakości bulw średnio późnych i późnych odmian ziemniaka jadalnego. Acta Agrophysica, 2013, 20(3), 411-422.

Kowalik P. J., Scalenghe R. 2009. Water needs of energy crops - one of the environmental problems of Poland., 1-9.

Lin C. S., Binns M. R. 1988. A Superiority Measure of Cultivar Performance for Cultivar $\times$ Location Data. Canadian Journal of Plant Science, 68(1), 193-198. DOI: 10.4141/ cjps88-018

Losert D., Maurer H. P., Marulanda J. J., Würschum T. 2017. Phenotypic and genotypic analyses of diversity and breeding progress in European triticale $(\times$ Triticosecale Wittmack). Plant Breeding, 136(1), 18-27. DOI: 10.1111/ pbr. 12433

Mądry W., Iwańska M. 2011 a. Ilościowe miary szerokiej adaptacji odmian i ich zastosowanie w doświadczeniach wstępnych $\mathrm{z}$ pszenicą ozimą. Biul. IHAR 260/261: $81-95$.

Mądry W., Iwańska M. 2011 b. Przydatność metod oraz miar statystycznych do oceny stabilności i adaptacji odmian: przegląd literatury. Biul. IHAR 260/261: 193 218.

Mądry W., Mańkowski D. R., Kaczmarek Z., Krajewski P., Studnicki M. 2010. Metody statystyczne oparte na modelach liniowych w zastosowaniach do doświadczalnictwa, genetyki i hodowli roślin. Biuletyn IHAR, 34, 13-163.

Mądry W., Rajfura A. 2003. Analiza statystyczna miar stabilności na podstawie danych w klasyfikacji genotypy x środowiska. Część III. Porównanie estymatorów i testów w rozpatrywanych modelach z dwóch grup oraz przykład liczbowy. Colloquium Biometricum, 33, 221-234.

Nowacki W., Barbaś P., Boguszewska-Mańkowska D., Jankowska J., Pietraszko M., Trawczyński C., Zarzyńska K., Michalak K., Urbanowicz J. 2019. Charakterystyka Krajowego rejestru odmian ziemniaka. IHAR-PIB, Jadwisin ss. 43.

Oleksiak T., Mańkowski D. R. 2003. Ocena stabilności plonowania wybranych odmian pszenicy ozimej na podstawie wyników badań ankietowych z lat 1990-2001. Biuletyn IHAR, 228, 4-10.

Padarewski J., Mądry W. 2012. Zastosowania modelu AMMI do analizy reakcji odmian na środowiska. Biul. IHAR, 263, 161-188.

PTG 2009. Klasyfikacja uziarnienia gleb i utworów mineralnych - PTG 2008. Roczn. Glebozn. - Soil Sci. Ann., 60 (2), 5-16.

Roztropowicz S. 1999. Metodyka obserwacji, pomiarów 
i pobierania prób w agrotechnicznych doświadczeniach z ziemniakiem. (T. 1-200). Instytut Hodowli i Aklimatyzacji Roślin, Oddział w Jadwisinie 1-50.

Rymuza K., Radzka E., Lenartowicz T. 2017. Analiza interakcji genotypowo-środowiskowej średnio wczesnych jadalnych odmian ziemniaka. Biuletyn IHAR, (281), 59-68.

Sawicka B., Krochmal-Marczak B. 2005. Wpływ czynników agrometeorologicznych na długość faz rozwojowych bardzo wczesnych i wczesnych odmian ziemniaka. Acta Agrophysica, 6(1), 225-236.

Sawicka B., Pszczółkowski P. 2004. Fenotypowa zmienność struktury plonu odmian ziemniaka w warunkach środkowo-wschodniej Polski. Biuletyn IHAR, (232), 53-66.

Skowera B., Kopcińska J., Kopeć B.2014. Changes of thermal and precipitation conditions in Poland in 1971-
StatSoft Polska Sp. z o.o. 2018. Zestaw Przyrodnika wersja 1.0. www.statsoft.pl.

TIBCO Software Inc. 2017. http://statistica.io

Tollenaar M., Lee E. A. 2002. Yield potential, yield stability and stress tolerance in maize. Field Crops Research, 75(2-3), 161-169. DOI: 10.1016/S0378-4290(02)000242

Wójtowicz M. 2013. Rola czynników środowiskowych i agrotechnicznych w kształtowaniu wielkości i jakości plonu rzepaku ozimego (Brassica napus L.). Monografie i rozprawy naukowe 45/2013: 1-111. IHAR-PIB. Radzików

Yan W., Kang M. S., Ma B., Woods S., Cornelius P. L. 2007. GGE Biplot vs. AMMI Analysis of Genotype-byEnvironment Data. Crop Science, 47(2), 643-653. DOI: 10.2135/cropsci2006.06.0374 